\title{
A COMPARATIVE ANALYSIS ON HOUSING POLICIES IN TURKEY AND LITHUANIA
}

\author{
Feyzullah YETGIN ${ }^{1}$ and Natalija LEPKOVA ${ }^{2}$ \\ 1 Emlak Real Estate Investment Company; Department of Social Sciences Institute, \\ Kadir Has University, Meric Cad. Gardenya 7B Plaza Kat: 7 Atasehir, Istanbul, Turkey \\ E-mail: fyetgin@emlakgyo.com.tr, tel: +900 21645648 59, fax: +9002164564873 \\ 2 Department of Construction Economics and Property Management, Vilnius Gediminas \\ Technical University, Sauletekio al. 11, LT-10223 Vilnius, Lithuania \\ E-mail: Natalija.Lepkova@st.vtu.lt, tel: +370 5 2745236, fax: +370 52745235
}

Received 23 November 2005; accepted 20 October 2006

\begin{abstract}
The housing sector is a very important sector in the national economy worldwide. The greater importance of the housing sector is broadly defined, to include financing, upgrading, repairs, management, valuation, taxation and population. The article presents a comparative analysis on housing policies in Turkey and Lithuania. The housing strategies their differences and similarities - of Turkey and Lithuania are presented in the article. Strategic principles and preferences of housing are analysed in the countries under investigation. Some economic aspects are underlined. The policies of social housing of investigated countries are presented. The housing problems of both analysed countries are described. Special attention is paid to sustainable housing and social cohesion in housing.
\end{abstract}

KEYWORDS: Housing; Housing Policy; Housing Strategy

\section{INTRODUCTION}

Numerous studies have been made concerning housing markets. However, when we look into the related literature we find out that there are few comparative studies between countries, and those that we have are generally focused on the cases observed in the developed countries.

Comparative studies provide general information on the concerned countries and detailed information on their social and economic situations and government policies. The information obtained from results of such studies has shown the way to the application for other countries.
Lithuania, which is among the countries subjected to such studies, regained its independence in 1990 and since then it undergoes a new transformation process. After its accession to the EU, implementation of an integration process started as a rapidly developing dynamic structure among the Baltic Countries. On the other hand, Turkey is another country, which achieved an important success on its way to EU membership on 17-12-2004 and which accomplished an important stage in the negotiation process.

Turkey is among 25 leading world countries according to its economic growth and is an important country due to its geopolitical position. It is also a continuously growing country

International Journal of Strategic Property Management ISSN 1648-715X print / ISSN 1648-9179 online (C 2007 Vilnius Gediminas Technical University http://www.ijspm.vgtu.lt 
open to outside policies, which have been applied after 1980.

Although economic and demographic dimensions of the mentioned countries differ, such common existing issues like corporal infrastructure and socio-economic aspects made it necessary to take certain similar measures with respect to the housing shortage and policies in particular, and it was the essence of this study.

Comparative studies between Lithuania and Turkey showed that both countries have developed policies according to their demographic and economic characteristics. Different strategies have been introduced according to government policies. It was observed at the end of the study that various financial and corporal institutions were established in both countries in order to satisfy housing shortage. By means of joint cooperation of the public and private sectors, studies on the housing shortage have been carried out and certain aids have been provided to help lower income groups to obtain dwellings. The housing shortage issue is a priority in order to ensure social justice and to meet housing needs, which is a constitutional right as well. However, in Lithuania, satisfaction of housing needs has a lower priority among other problems dealt with by the Government of Lithuania.

There are numerous studies about the housing sector and policies of different countries, for instance, Houston (2005) analysed theoretical aspects of housing and housing problems. Kim (2004) explored the nexus between housing and Korean economy. Lahr and Gibbs (2002), Cutts and Olsen (2002), Nothaft and Perry (2002), Ortalo-Magne and Rady (2002), Seko (2002) provided economic analyses of policy initiatives pertaining to housing vouchers, homeownership, and housing finance reform. Gallent (2005) concentrated on regional housing figures in England-policy, politics and ownership. Most of these studies deal with housing policies of various countries but there are only a few comparative studies between countries. The existing comparative studies aim at understanding the dynamics and features of various national housing policies. For example, Wong's (2004) study compares Hong Kong and Singapore and examines and compares the role of governments, private and public sectors of the said countries in matters related to housing sector. Belniak (2004) studied the situation of Polish real estate markets and housing sector in the European Union process. Ivanicka and Spirkova (2004) examined housing financing system of Slovakia in the process of EU integration. Housing policies are discussed in the studies of Keivani et al., (2004). The "Report of the Regional Workshop on Housing and Environment" of the United Nations Centre for Human Settlements (HABITAT) (UNCHS, 2000) is a very detailed work examining different countries on their environment-friendly construction practices and the role of private sector on housing supply in these countries; the report also examines housing policies of the countries, the situation of housing markets and reform efforts in these countries. In order to obtain information about countries and their housing policies, the role of the private sector is examined and housing markets of the countries are analyzed in detail in this report.

All of these studies provide a great deal of information about various countries. They give good examples on housing markets of some countries in the EU membership process; the examples could be very useful to Turkey, which is also in the EU membership process.

However, in contrast to the above-mentioned studies, this article contributes by investigating Lithuania, an EU member, and Turkey, a country in EU membership process, and deducts information by comparing these two countries.

\section{HOUSING SITUATION}

\subsection{Housing situation in Turkey}

Turkey has been facing a housing shortage since the 1950s when the industrialization process led to rapid urbanization. Low-income 
levels and poor living standards in the countryside and social and political disorder in certain rural areas forced a large number of people to migrate to large cities.

Until 1980, the government policies related to housing focused on encouraging the construction of social housing with government loans, providing tax exemptions and discouraging luxury houses via additional taxes. Unfortunately, the government was not successful in increasing the number of dwellings; the shanty house areas could not be improved and infrastructure remained insufficient.

Economic steps taken by the government in 1980 in order to improve the Turkish economy negatively affected the housing sector. Consequently, the housing deficit increased and investment in this sector decreased. However, the importance of the housing sector was realized when more than 300 sectors, which provided input for the housing sector, were also affected. From then on, government policies were changed towards the improvement of the sector, and investment in housing increased substantially. Some important steps taken to support this change were the establishment of the Mass Housing Fund and certain changes to encourage new dwelling unit construction.

In order to increase the number of homeowners, the government has provided loans for mass housing projects through social security institutions (such as SSK, Bagkur) as well as
Türkiye Emlak Bankasi (Emlak Bank). Although this policy increased dwelling construction, it has not been successful in increasing the number of homeowners. In the 1980's, for the purpose of encouraging the construction of small houses, the loans given by SSK and Bagkur were contingent upon the fact that the houses to be constructed would not be bigger than 100 sq. meters. This policy could not be implemented successfully, and in 1998 this policy was abolished. During the recent bank restructuring, Emlak Bank was shut down and all banking functions merged with Halkbank. All real estate related activities are continuing under Emlak Reic.

Given the rapid urbanization of the population, the aggregate demand for housing has exceeded the aggregate supply. The government has failed to solve the housing problem, although improvements have been made. Today, the government is still working on the problem with various approaches but the number of luxury and shanty houses is increasing more rapidly than the needed social and mass housing.

Turkey's population is estimated to be 69,63 million by mid-2002 and the population growth rate is approximately $1,5 \%$ per year. The local civilian work force is about 22,4 million. The population is much younger compared to $\mathrm{Eu}-$ ropean countries. Approximately $70 \%$ of the population is below the age of 35 (see Table 1 ).

Table 1. Mid-year population, urbanization level, and population density

\begin{tabular}{|c|c|c|c|c|c|c|c|c|}
\hline \multirow{2}{*}{ Country } & \multicolumn{4}{|c|}{ Mid-year population (Million) } & \multicolumn{2}{|c|}{ Urbanization level a/ } & \multirow{2}{*}{$\begin{array}{l}\text { Density b/ } \\
\text { (Square km) }\end{array}$} & \multirow{2}{*}{$\begin{array}{l}2003 \text { Mid-year } \\
\text { population (Million) }\end{array}$} \\
\hline & 1993 & 1997 & 2001 & 2002 & 1997 & 2002 & & \\
\hline Lith & 3,68 & 3,58 & 3,48 & 3,47 & 67,5 & 66,9 & 52,9 & 3,45 \\
\hline Turkey & 59,49 & 64,02 & 68,53 & 69,63 & $63,2 \mathrm{t} /$ & $65,8 \mathrm{t} /$ & 89,9 & $69,63 \mathrm{~d} /$ \\
\hline
\end{tabular}

a/ Urbanization level is defined as the percentage of population residing in urban areas in each country according to national definitions.

b/ Population per square kilometre of surface area. Computations were based using the latest available data for population. Surface area pertain to land area and inland water.

d/ 2002 .

t/ Urban areas refer to municipalities with more than 25000 inhabitants.

Source: UNECE (2000); UNECE (2004). 
As for Turkey, the increasing population growth has resulted in higher ratios of unemployment which is aggravated by the financial crises. The said inflation ratios as well as the real interests have prevented the provision of long-term housing financing. The inflation rate in Turkey has shown a declining trend since the year of 2003; however, it is still not sufficient enough for the provision of sustainable housing credits.

\subsection{Housing situation in Lithuania}

In the post-war period urban growth in Lithuania was very dynamic. The share of urban population increased from $23 \%$ in 1939 to $66,9 \%$ in 2002 . Urban growth was the highest in 1966-1970 due to a yearly migration of 57,000 inhabitants from rural to urban areas, which correspondingly led to the depopulation and decline of rural areas. In Lithuania, there are 111 towns (according to the national classification all settlements with more than 3,000 inhabitants are towns). Almost $40 \%$ of the inhabitants live in the five biggest cities; $15 \%$ of the total population is concentrated in Vilnius (capital of Lithuania). The high level of urban concentration, together with employment restructuring, intensifies regional differences in the demand for and the supply of housing (see Table 1) (UNECE, 2000).

Lithuania has a relatively high amount of homes per 1,000 inhabitants compared to most other countries in transition. Nevertheless, economic growth and growth in household purchasing power, the need to replace outworn stock, to cope with future demographic changes and to address current housing market disequilibria (e.g. overcrowding), all point to some urgency in increasing new housing output. The current housing development process does not appear to work smoothly, unlike in some parts of the high-end of the market. Lithuania's housing sector is well into the process of transition: the housing stock is largely privatized, some new types of housing organizations and intermediaries have developed and there are certain arrangements for trading and mortgaging residential property.
The formation of households is directly influenced by a change in population and households. The population has been decreasing in Lithuania in recent years. The number of elderly people has been increasing (25\% of the households are over 60 years of age). The number of children under 14 years of age has been decreasing, with $18 \%$ of the population younger than 30 years of age. The majority, i.e. $57 \%$ of the population, is older than 30 years of age. The decreasing number and ageing population reduces the housing demand; however, the increasing number of households (due to decreasing size) maintains a stable housing demand.

At the end of 2002, Lithuania had 1,356,160 dwellings and 1,461,065 households. The housing shortage accounts for $7 \%$ while in Western and Northern Europe it makes up 2\%. Lithuania has 365 dwellings per 1,000 inhabitants, while the above countries have 450 dwellings; thus the useful space area per capita accounts for $22,1 \mathrm{~m}^{2}$ respectively.

\section{EFFECTS OF POPULATION TO THE HOUSING}

Housing demand and construction differs from city to city. In provinces where a large immigrant population has caused an increase in demand, construction is also increasing. Similar increase is shown in areas where tourism is rapidly developing. The four main reasons for the increase in housing demand in Turkey are:

- Population increase;

- Immigration to the urban areas;

- Married couples buying their own homes for the first time;

- Young people preferring to live apart from their family.

Unlike the case in developed countries, the urbanization process in Turkey has occurred as a migration phenomenon in which urban poverty was preferred to rural. At the end of 2000, $44 \%$ of the urban population, $23 \%$ of which is in Istanbul, was expected to be settled in cities whose population was over one million. 
It is estimated that an average annual urbanization rate between 1995 and 2000 was $4,7 \%$. The urban population, which was estimated to be 34,4 million in 1995, was expected to reach 43,3 million at the end of 2002 and to constitute $65,8 \%$ of the total population.

From 2000 to 2005, it was expected that the rate of urbanization would be realized by an average of $4,75 \%$ annually. Urban population, which was estimated to be 43,3 million in 2000 , was expected to reach 54,7 million by the end of 2005 constituting $78 \%$ of the total population.

The major challenges of the housing sector in Lithuania today are associated with the excessively high share of privately owned housing (close to 97\%), historically low rates of housing construction, overcrowding and affordability constraints. There is a high pent up demand for housing demonstrated by the waiting list for government subsidies (soft loans or rental dwellings from municipalities) and the growing mismatch between the size of dwell- ing and households' needs (e.g. $20 \%$ of threegeneration families live in one and two room dwellings). The average price of dwellings is 8 times the average disposable household income and could be as high as 20 times in the case of a newly built individual house. Housing choices are very limited (see Table 2).

As a result, low-income households earning less than 700 LTL a month (30\% of total) have no choice but to live in social rental housing or in their current dwelling ( 1 US $\$ \approx 2,65$ LTL). Middle-income households (801 to 1500 LTL a month), which represent $40 \%$ of total, could afford to buy a flat in most of the municipalities outside the centre. One of the issues looming on the horizon is the age of the housing stock in Lithuania. Approximately 70\% of housing stock is over 20 years old and is in need of repair, renovation or, at minimum, proper maintenance (Tsenkova, 2004).

Home ownership is widespread in Turkey (see Table 3). According to the data of the Turkish Statistical Institute for 1990, over 70\% of

Table 2. Stock of dwellings in Lithuania (useful floor space; in million $\mathrm{m}^{2}$ )

\begin{tabular}{lcccccccccc}
\hline & 1995 & 1996 & 1997 & 1998 & 1999 & 2000 & 2001 & 2002 & 2003 & 2004 \\
\hline Total & 74,2 & 75,5 & 76,3 & 78,3 & 79,7 & 79,5 & 79,4 & 79,5 & 79,4 & 80,2 \\
$\begin{array}{l}\text { Urban stock of } \\
\text { dwellings }\end{array}$ & 45,5 & 47,0 & 47,7 & 49,5 & 50,8 & 50,6 & 50,2 & 50,4 & 50,1 & 50,8 \\
$\begin{array}{l}\text { Rural stock of } \\
\text { dwellings }\end{array}$ & 28,7 & 28,5 & 28,6 & 28,8 & 28,9 & 28,9 & 29,2 & 29,1 & 29,3 & 29,4 \\
\hline
\end{tabular}

Source: Statistics Lithuania (2005).

Table 3. Homeownership Growth Initiatives

\begin{tabular}{llllll}
\hline Country & $\begin{array}{l}\text { Population/ } \\
\text { Home }\end{array}$ & $\begin{array}{l}\text { Annual Housing } \\
\text { Construction }\end{array}$ & Ownership (\%) & Population (000) & $\begin{array}{l}\text { Number of } \\
\text { Households }\end{array}$ \\
\hline France & 2,1 & 268,000 & 54 & 58,020 & 27,807 \\
USA & 2,6 & - & 68 & 281,421 & 104,705 \\
Japan & 2,7 & $1,229,843$ & 60 & 126,926 & 46,782 \\
Germany & 2,3 & 268,900 & 41 & 81,539 & 28,413 \\
Canada & 2,5 & $\mathrm{n} / \mathrm{a}$ & $\mathrm{n} / \mathrm{a}$ & 28,847 & 11,699 \\
England & 2,3 & 178,857 & 67 & 58,612 & 25,382 \\
Turkey & 4,9 & 268,400 & 70 & 69,700 & 14,800 \\
Lithuania & 2,4 & $\mathrm{n} / \mathrm{a}$ & 97 & 3,435 & 1,461 \\
\hline
\end{tabular}

* n/a not available data

Source: GYODER (2005); Turkish Statistical Institute (2004b). 
the population owned their own houses. More than $90 \%$ of properties are $100 \%$ equity financed.

Some of the Home Ownership Growth Initiatives include:

- Introduction of long-term real estate loans by Turkish banks (3- 20 years);

-3-5 year zero interest rate developers' loans;

- Price incentives by municipalities;

- Earthquake funds: there is a strong surge of support for Turkey in the aftermath of the earthquake of 17 August 1999, and the substantial international assistance in the range of US\$3-4 billion is expected to help Turkey recover rapidly;

- Construction of residential units which are in higher demand.

Because of such factors as a rapidly growing, young population and the speed at which urbanization is occurring, Turkey finds itself in a position where it has to make significantly more housing available. Its rapid pace of urbanization, its population density and its centrality to the Turkish economy have resulted in Istanbul having been exposed to housing market developments early and intensively.

Even if population growth alone is taken into consideration, it is evident that there is an annual need in Turkey of approximately 450-500 thousand units of new housing. In this respect, with an annual population increase of $3,3 \%$, Istanbul is likely to be the most important metropolis in the Middle East and Eastern Europe.

Assuming that current economic policies are maintained and that the decline in inflation continues, it can be concluded that the fall in interest rates on real estate loans as well as the lengthening of the maturity of loans will continue. In this case, there is a high prospect for an increase in the availability of quality housing to middle-income groups that had previously only been available to upper and upper-middle-income groups.

These two factors and others that support them - such as an increase in awareness of the earthquake threat and changes in consumer habits - are likely to make important contributions to the housing market in the upcoming period.

The earthquakes of 1999 generated not only increased awareness in the economy but also heightened concern for the institutionalization and proven quality of construction and real estate development firms. The creation of building inspection mechanisms and selectivity in the granting of construction permits are now more important for the public.

In a sector that experienced serious stagnation in the aftermath of the Russian Crisis in 1998, of the earthquake of 17 August 1999 and of the recent economical and political instability, declining interest rates stimulate a rather delayed demand. Accordingly, the volume of business carried out for the middle and upper-income groups, which make up a significant part of the population, increases.

Turkey's average annual population growth rate of $1,94 \%$ over the past 20 years and high urbanization rate have been the driving forces behind the development of the Turkish housing sector, which accounts for some $4 \%$ of GNP for 2001.

As seen in Table 4, the differences in the speed of population growth and the ratios of urbanization have an obvious impact on the share of the housing sector within the GNP. In Turkey, the share of the housing sector is 4\%; whereas, in Lithuania, it makes up 2,8\% indicating a lower ratio.

By 2013, Turkey's population is estimated to reach 87 million. Due to population growth and continued urbanization, Turkey would require an additional 5,5 million housing units. Added to the existing housing deficit, this represents a requirement for more than 500,000 new housing units to be built each year. Additionally, with a growing economy and rapid urban expansion, there is a need for the construction of more commercial/office/professional buildings. Likewise shopping malls and retail establishments need to be built as consumer 
Table 4. Gross National Product by sectors for 2004

\begin{tabular}{lll}
\hline & Lithuania & Turkey \\
\cline { 2 - 3 } & Structure $\%$ & 100 \\
\hline Total & 100 & 11 \\
Agriculture, Hunting, Forestry, Fishing & 2,3 & 25 \\
Manufacturing \& Industry & 14,7 & 4 \\
Housing & 2,8 & 60 \\
Others & 80,2 & \\
\hline
\end{tabular}

Source: Turkish Statistical Institute (2004a); Statistics Lithuania (2005).

spending is increased. Tourism development continues to generate new construction projects. As in other countries, the construction industry is highly susceptible to macro economic factors. Government projects, mostly infrastructure projects such as highways, bridges, airports, seaports, etc., have been slowed by the economic crises. Residential and industrial buildings are mostly completed by the private sector. While this portion of the sector is also influenced by global financial conditions, there is still growth, albeit at a slower rate. Expectation for 17 October 2005, when Turkey started its negotiations with the EU on full EU membership, seemed to influence performance of the industry in the coming years.

Housing investments are considered as an important indicator of country's economy. The investments in the housing sector account for $4 \%$ of GDP and 15-30\% of fixed capital investments. Furthermore, the urbanisation rate in Turkey is too high. The high urbanisation rate based on migrations is the result of incorrect socio-economic policies, the failure of the state to allot satisfactory amount of resources for investment and the inconsistency in the distribution of the investments throughout the country.

Particularly, the migration oriented towards big cities complicates the existing problems; leads to squatter building and illegal constructions and creates negative impacts on the environment. When investments to the infrastructure and social services fall short of meet- ing the demands, the problems of urban population related with economic and social life remain unsolved and they gradually increase. Therefore, the housing problem in Turkey is a qualitative problem as well as a quantitative.

In Lithuania, housing construction declined significantly compared to the situation in 1990 when 22,100 dwellings were constructed; in 2002 , only 4,562 new dwellings were constructed. The annual construction of new housing accounts for $0,3 \%$ of the total housing stock, and the annual turnover on the market accounts for $2,7 \%$ of the existing housing stock, while the average EU indicators are 1,5\% and $3,5 \%$ respectively. The reduced construction scope within the mentioned period resulted from a decrease of direct public funding, and the private sector did not compensate for such a decline. This resulted from the reduced income of the population, high expenditures for the new infrastructure, the limited supply of plots for construction and the unresolved issues in relation to the restoration of ownership rights to land. The studies assessed the construction of new housing as being insufficient due to high prices and poor variety (Government of the Republic of Lithuania, 2004).

The labour force in Turkey has grown much more slowly than population during the 1990s (see Table 5). Notwithstanding, the growth rate of the Turkish economy, despite its impressive levels in 1990s, has not been sufficiently high to generate enough employment opportunities for the fast growing labour force: a problem 
which has been further aggravated by substantial migration from rural to urban areas. Additionally, due to the crisis of 2001, a significant amount of white collar workers have also lost their jobs for the first time in the recent Turkish Republic history.

The number of unemployed was 1,4 million in 2000. In 2001, the unemployment increased to 1,9 million people in Turkey. The rate of unemployment was $8,4 \%$ in 2001 , and it made up a total yearly average of $14,4 \%$ when taken with the rate of underemployment of $6,0 \%$.

The diminution of the Lithuanian population also results in a decrease of the unemployment figures. The low inflation rate of this country has enabled the provision of appropriate and long-term payment plans (see Table 6).

\section{SOCIAL EXCLUSION AND POVERTY, HOUSING PROBLEMS}

\subsection{Situation in Lithuania}

The problem and the concept of social exclusion are new in the Lithuanian context. The process of transition in Lithuania has already brought drastic changes to everyday life for ordinary people.

For large groups of the population, the standard of living remains low and does not allow people to lead their life in accordance with the Human Development principle. Rural residents are particularly vulnerable in this respect. In 1999, food took up as much as $62,6 \%$ of a farmer's consumer expenditure while the national average was $45,7 \%$. Employment income is rapidly being replaced by so-

Table 5. Developments in domestic labour market in Turkey

\begin{tabular}{|c|c|c|c|c|c|c|c|c|}
\hline & & 1990 & 1999 & 2000 & 2001 & 2002 & 2003 & 2004 \\
\hline Civilian Labor Force & 1 & 20,151 & 23,187 & 22,031 & 23,491 & 24,289 & 23,206 & 24,289 \\
\hline Civilian Employment & 1 & 18,539 & 21,413 & 20,579 & 21,14 & 21,14 & 21,147 & 21,791 \\
\hline Unemployment & & $8,0 \%$ & $7,7 \%$ & $6,6 \%$ & $8,4 \%$ & $10,3 \%$ & $10,5 \%$ & $10,3 \%$ \\
\hline Underemployment & & $6,6 \%$ & $8,8 \%$ & $6,9 \%$ & $6,0 \%$ & $5,4 \%$ & $4,8 \%$ & $4,1 \%$ \\
\hline Total & & $15,2 \%$ & $16,5 \%$ & $13,5 \%$ & $14,4 \%$ & $15,7 \%$ & $15,3 \%$ & $14,4 \%$ \\
\hline
\end{tabular}

(1) $=$ in thousand people $-15+$ Age

Source: Turkish Statistical Institute (2004b).

Table 6. Main indicators of economic and social development in Lithuania, 1996-2004

\begin{tabular}{|c|c|c|c|c|c|c|c|c|c|}
\hline & 1996 & 1997 & 1998 & 1999 & 2000 & 2001 & 2002 & 2003 & 2004 \\
\hline $\begin{array}{l}\text { Annual average } \\
\text { population } \\
\text { number, thousand }\end{array}$ & 3601,6 & 3575,1 & 3549,3 & 3524,2 & 3499,5 & 3481,3 & 3469,1 & 3454,2 & 3435,7 \\
\hline $\begin{array}{l}\text { Unemployment } \\
\text { rate, by labour } \\
\text { force survey data, } \\
\%\end{array}$ & $\ldots$ & 14,1 & 13,2 & 14,6 & 16,4 & 17,4 & 13,8 & 12,4 & 11,4 \\
\hline $\begin{array}{l}\text { Inflation } \\
\text { (December } \\
\text { compared to } \\
\text { December of } \\
\text { previous year), \% }\end{array}$ & 13,1 & 8,4 & 2,4 & 0,3 & 1,4 & 2,0 & $-1,0$ & $-1,3$ & 2,9 \\
\hline
\end{tabular}

Source: Statistics Lithuania (2005). 
cial assistance benefits. In 1999, the level of poverty, $(28,2 \%)$ was significantly higher in rural areas compared to the national average of $15,8 \%$. Consequently, consumer expenditure on education, health and culture in rural areas is several times lower than in the cities.

According to the population data of 2001 and number of residential houses, the housing sector in Lithuania has extensively diversified structure. According to the data, 99\% of Lithuanians reside in traditional dwellings $(38,1 \%$ in detached houses, $60,9 \%$ in apartments and $1 \%$ in hotels and residential domiciles). $79 \%$ of urban residents live in apartments. In rural areas, the number of houses older than 50 years is quite high and there is a certain need to build new houses and renew the existing buildings. Besides, research shows that only $42,8 \%$ of households declare a very good life standard, $47 \%$ declare satisfactory and 10,2\% declare bad or very bad life standards. These assessments are based on factors such as the space, location and heating conditions of the house. In Lithuania, investigation revealed that the range of the households with low income appeared to differ 12-15 times from the highest income (Jonaitis and Naimavičienè, 2004).

\subsection{Situation in Turkey}

In urban areas and large city centres like Istanbul, Ankara and Izmir, the average income is approximately US\$500 per month. Professionals working in the field of finance (banks, insurance companies, investment funds, etc.) may have salaries of up to US $\$ 3,000$ per month. Total annual earnings of approximately $0,5 \%-1 \%$ of Turkish population are over US $\$ 500,000$. The Government fixed a minimum wage, which is annually adjusted according to inflation. Currently, the minimum wage is approximately US $\$ 140$ per month.

$36 \%$ of Turkey's population has annual income under US $\$ 1,500$. The recognized poverty line for a family of four is US\$474 a month. It is rather a global phenomenon that poverty steadily grows and deepens. According to vari- ous analyses of the United Nations, some 1,1 billion people, half of whom live in extreme poverty, are defined as "poor". This was pointed out during the World Summit for Social Development in Copenhagen in 1995. Turkey is not an exception to this situation. The lack of sufficient housing, which is both a basic need and a very important consumption item for human well-being, reflects the extent of poverty which many socioeconomic groups experience. "Gecekondu", which is the Turkish version of squatter housing seen in every developing country, provides shelter for the urban poor and "have-nots" in and around big cities and invades more and more rural land every day. Of the estimated total urban population of 37,8 million (i.e. $60,9 \%$ of the total population) in 1995, nearly a quarter still live in gecekondu-type settlements. However, the formation of gecekondu has not been stopped due both to the scarcity of national financial resources and to rising poverty levels (GYODER, 2005).

While abject poverty (defined as pervasive poverty below biological or nutritional standards) may not be a problem in Turkey, extensive relative poverty is, and the number of poor with less than adequate nutrition, housing and health standards has been increasing in recent years. Social security institutions in Turkey have increasing financial problems. The imbalance between active and passive insurers requires organizational changes.

The fact that many people in both of these countries live below the poverty line has necessitated a supportive role of governments to meet the housing needs. The Turkish Directorate of Public Housing has been constructing dwellings for low-income groups on a long-term instalment basis, thus enabling them to have their own dwellings. On the other hand, the Government of Lithuania realizes this through various subventions provided to this group. Many Lithuanian citizens, however, are still waiting in queue to have their own dwellings.

We observe that support to low-income groups in both countries is a necessity. Even 
so, it seems impossible to meet this demand in such a short period.

The main problems of the policies applied after 1980 can be summarized as follows:

- Rapid urban population growth;

- The misuse of dwelling funds;

- The adverse effect of increasing rents for low-income groups;

- The deficiency of housing loan system; and

- The increase in luxury houses rather than social houses.

According to the number of issued Construction Permits, the number of residential buildings constructed each year has shown continuous growth, except in 1994 and during the recent economic crisis. However, the number of Occupancy Permits lags behind at approximately $40 \%-50 \%$ of the number of Construction Permits normally issued on a year-to-year basis.

As of 2000, it is estimated that there is a total of about 14,8 million houses, 10,2 million of which are located in regions with a population of 20,000 and over.

According to a research conducted by the Turkish State Planning Department, the total housing shortage in 1998 made up approximately 500,000 units. Between 2000 and 2005, additional housing demand making up $2,714,000$ in settlements with a population of 20,000 or more was planned due to demographic developments. Additionally, it was planned that 72,200 houses per year, a total of 361,000 in five years, would be needed for some other reasons like renewals and natural disasters, including former needs caused by disasters. Consequently, the total housing demands stemming from urbanization, popula- tion growth, renewal and natural disasters made up 3,075,000 in the plan period. Considering the existing housing demand, the total housing demand was about 5 million by the year 2005 .

The unfulfilment of the housing demand leads to unauthorized construction to fill the gap. Due to the lack of data on the number of buildings since 1984, information about building and illegal building stock is limited. It is estimated that the illegal building stock in the three largest cities makes up about 2 million and such trend of construction throughout the country spoils the quality of buildings and environment in the cities. Uncontrolled building stock aggravates taking measures against disasters especially against flood, earthquake and fire.

Investment in residential and non-residential buildings by the number of buildings and total areas are given in the graphs presented below. The values displayed in the schedules and the graphs are taken from building licences.

The evolution of the building stock is shown in Table 7. When housing stocks are inspected, we see a remarkable increase in the number of licensed residential buildings between 1929 and 2000; nevertheless, considering the fact that the number of unlicensed residential buildings is $16,000,000$, we find out that only $30-35 \%$ of total housing stock is licensed. This picture is very important in the way that it shows us the gravity of unplanned, shanty settlements.

Accordingly, the building stock until 1950 accounted for 5,9\% of the stock in 2000 . The urbanisation rate in this period is low; and the dwellings produced could only meet the demand of urbanisation of a low rate.

Table 7. Building stocks according to building licences

\begin{tabular}{lllllllll}
\hline$(000)$ & -1929 & $1929-$ & $1929-$ & $1929-$ & $1929-$ & $1929-$ & $1929-$ & $1929-$ \\
Units & & 1939 & 1949 & 1959 & 1969 & 1979 & 1989 & 2000 \\
\hline Turkey & 100 & 165 & 297 & 567 & 1079 & 2092 & 3484 & 5019 \\
\hline
\end{tabular}

Source: The Building Information Centre (2004). 
The building stock from 1950 to 1960 is twice as large as in the previous period. This increase was caused by the advance of urbanisation rate to $6 \%$, the increase in the jerry building, the outcome of build-and-sell concept and the beginning of state initiatives to solve housing problems.

The "Housing Demand Research of Turkey" of 2000-2010 carried out by the Prime Ministry Housing Undersecretariat shows that illegal construction of buildings in Turkey has reached $40 \%$ even when considered in respect of only building permits (Housing Undersecretariat, 2002). In the urban areas, $62 \%$ of the housing stock in average are licensed and authorised. When permits to use buildings are taken instead of the licences, this number falls to $33 \%$. In other words, 67 out of 100 buildings are illegal.

According to the estimates of DPT (State Planning Organisation), the housing demand was expected to be around 633,600 in 2004 (State Planning Organisation, 2001).

\section{HOUSING RENTAL MARKET AND PROBLEMS}

According to the Housing Ownership Research carried out by the Housing Undersecretariat, $35-40 \%$ of Turkish households rent dwellings. Dwelling ownership rate in central areas of a city has declined to $58,2 \%$. The state is inevitably anticipated to subvent the production of rented houses under these conditions (Housing Undersecretariat, 2002).

During this research, it was determined that the housing stock was above the demand and needs in some cities; however, people could not get rid of tenancy due to the failure to provide dwellings for the sector in need. The same research showed that $1 / 3$ of the build-and-sell supply mechanisms and the building stock is given to the tenancy sector.

Examination of housing preferences and habits of Turkish households according to the statistics of 2001 provided by the Turkish Institution of Statistics shows that $59,8 \%$ of households own a house and $31,6 \%$ of households are tenants (mostly in apartments). The remaining part consists of households which live in public dwellings or which do not pay rent even though they do not own a house.

In Lithuania, the dwelling rental market does not exist. In EU countries, rental housing accounts for $10 \%$ of the total housing stock. Lithuania feels a shortage of rental housing, especially for low-income families (young and elderly families). The prices of private rental housing vary depending on location and housing standards, and the prices of municipal social housing are lower ten times. Social housing accounts for only $2,4 \%$ of the total housing stock. The development of social housing has been slowing down as a result of reduced public and municipal investments.

In 2001, enumerations reveal an overall reduction of the housing stock; both urban and rural areas experienced a decrease in the number of dwellings. Lithuania Statistics explains that the decrease in the housing stock was due to a double counting error in previous years (Jonaitis and Naimavičiené, 2003).

One of the major problems in Lithuania is that low-income families, which cannot afford to maintain their housing, have poor opportunities to select housing. Young low-income families cannot afford to purchase or rent housing on the market. This leads to restricted mobility and does not encourage market dynamics.

The housings with a $35-40 \%$ of renting availability in Turkey are almost non-existent in Lithuania. Owing to the insufficient housing supply, growing housing demands and the increased population and immigration rates, the number of such dwellings is rapidly diminishing. This situation also leads to an extreme increase of renting prices, and, in turn, lowincome Turkish citizens are faced with a constantly augmenting rent burden.

The insufficient housing production in Lithuania has stipulated the provision of subventions for the younger population. In Lithuania, the problem of insufficient number of 
dwellings available for rent can partly be solved by living with parents.

Examination of dwelling preferences in both countries shows that Lithuanian dwelling owners tend to opt for 2-3 room compositions; whereas Turkish dwelling owners prefer 3-4 room compositions due to the prevalent traditional family structure (see Table 8).

When we look at the residential and nonresidential real estate production in both countries, we see that Turkey primarily witnesses construction of residential buildings and in Lithuania construction of non-residential buildings prevails; the fact can be explained by the demographical structure as well as the policy and preferences of the Lithuanian Government (see Table 9).

Table 8. Size of households by tenure
Housing demand based on housing needs will vary according to the household or a person's life cycle. On a first level approach, individual housing needs depend mainly on the age of the person, the family situation and the number of persons (single, married, with children or without children, living with parents) (OECD, 2002).

\section{HOUSING POLICIES AND SUSTAINABILITY OF HOUSING}

\subsection{Housing policy in Lithuania}

The European Treaty identifies a number of activities related to housing and, implicitly, to the sustainability of housing. These include "the achievement of a high level of social pro-

\begin{tabular}{|c|c|c|c|c|c|c|c|c|c|}
\hline \multirow[t]{2}{*}{ Country } & & \multirow[t]{2}{*}{ Year } & \multirow{2}{*}{$\begin{array}{l}\text { Total } \\
\text { households }\end{array}$} & \multicolumn{6}{|c|}{ Households with the following number of persons: } \\
\hline & & & & 1 & 2 & 3 & 4 & 5 & 6 and more \\
\hline \multirow[t]{4}{*}{ Lithuania } & Total (100) & 2001 & 1284,5 & 327,1 & 343,2 & 268,9 & 234,6 & 74,6 & 36,1 \\
\hline & Owner $(\%)$ & & 91,1 & 87,0 & 93,1 & 90,8 & 92,9 & 94,0 & 92,8 \\
\hline & Renter $(\%)$ & & 6,8 & 7,6 & 5,6 & 8,1 & 6,4 & 5,6 & 6,9 \\
\hline & Other $(\%)$ & & $\ldots$ & $\ldots$ & $\ldots$ & $\ldots$ & $\ldots$ & $\ldots$ & $\ldots$ \\
\hline \multirow[t]{4}{*}{ Turkey } & Total (100) & 2000 & 15070 & 803 & 2098 & 2578 & 3535 & 2303 & 3753 \\
\hline & Owner (\%) & & 68,3 & 65,8 & 68,8 & 58,3 & 61,7 & 69,1 & 81,0 \\
\hline & Renter $(\%)$ & & 23,9 & 24,9 & 24,6 & 32,0 & 28,1 & 23,2 & 14,3 \\
\hline & Other $(\%)$ & & 7,8 & 9,5 & 6,5 & 9,7 & 10,2 & 7,6 & 4,7 \\
\hline
\end{tabular}

Source: UNECE (2004).

Table 9. Value of total construction put in place

\begin{tabular}{llllc}
\hline Country & Year & Total construction & $\begin{array}{l}\text { Residential } \\
\text { construction }\end{array}$ & $\begin{array}{l}\text { Non-residential } \\
\text { construction }\end{array}$ \\
\cline { 3 - 5 } & & In millions of US dollars $(\$)$ & as \% of total construction \\
\hline Lithuania & 1997 & $0,999,618$ & 7,0 & 93,0 \\
& 2001 & $1,048,855$ & 9,5 & 90,5 \\
& 2002 & $1,270,992$ & 10,7 & 89,3 \\
Turkey & 1993 & 70,694 & 78,7 & 21,3 \\
& 1997 & 984,981 & 74,7 & 25,3 \\
& 2001 & $5,298,086$ & 77,4 & 22,6 \\
& 2002 & $5,453,312$ & 67,6 & 32,4 \\
\hline
\end{tabular}

Source: UNECE (2004). 
tection and the improvement of the quality of the environment, the raising of the standard of living and the quality of life, and social cohesion...". The new draft constitution explicitly recognizes that housing assistance is a means of combating social exclusion and poverty, themselves indicators of unsustainable development (Lee, 2004).

Firstly, although the Government has reformed many legal, financial and institutional structures to create an infrastructure to support the housing sector, it has neglected to help the new owners understand their rights and responsibilities.

Secondly, in reaction to the compulsions practiced during the Soviet period, it is now constitutionally impossible to require owners of apartments to become members of homeowners' associations (condominium associations) to manage common property in multidwelling buildings. Elsewhere, this is a normal prerequisite for communal action to manage buildings. It is also normally one of several prerequisites for banks to be willing to lend for the renovation of common elements of apartment buildings.

Thirdly, because of the poverty of many households, a raft of housing-related subsidies -mostly in form of compensations for energy consumption and for purchase of new homes - has been developed. This does not provide the financial support and incentives that economists would properly look for, yet is proving to be a major drain on central government resources. It is, therefore, unrealistic to expect that the Government could provide any further widespread and continuing subsidies for housing renovation.

According to one estimate, the equivalent of at least 2,9\% of total Government expenditure $(0,7 \%$ of GDP) is presently devoted to housing, mainly in subsidies. The then main types of housing subsidy investigated by the Housing Study can be categorized as direct (onbudget), indirect (on-budget but not categorized as for housing) and implicit (public revenues foregone). Most of the subsidies are not tar- geted, i.e. they are available equally to all households. Those that are targeted, however, predominantly benefit households in the top three income deciles.

The cost to local governments incurred supporting the present housing policy has not been calculated. Many housing functions have been allocated to municipalities but no one has estimated the cost of the assigned duties, nor, therefore, the gap between revenue and required housing expenditures (we suspect that available revenues fall well short of the legislated need for housing expenditure). Few municipalities have carried out an assessment of the human resources required for housing management, and there is likely to be a substantial shortfall between the demand and the supply.

The housing strategy adopted by the Government encompasses a range of solutions which would go a long way to overcome these problems and to make the housing stock more sustainable. They aim to:

- increase the economic maintenance, repair and upgrading of housing (energyefficiency and structural improvements);

- improve housing affordability, especially for low income households;

- enhance the value of existing housing through local initiatives;

- improve housing choice by increasing the proportion of adequate rental housing and by enhancing mobility; and

- increase social cohesion, especially in large housing estates.

\subsection{Housing policy in Turkey}

In countries like Turkey, which have high rates of population increase and of migration from rural to urban areas, the demand for housing is also high. Housing needs of especially low-income groups is a problem in this process. As a result, construction of social housing and meeting the shelter needs of the lowincome groups became a preferential target. And Turkey has been assigning problems and 
needs brought about by rapid urbanization and population increase which determine the housing policy.

Major government policies related to housing in Turkey are inevitably affected by various factors. Therefore, through the context of the recent government policies, the priorities defined can be stated as follows (Housing Development Administration of Turkey, 2005):

- reducing uneven regional distribution and providing a balanced allocation of housing investments;

- preventing unauthorized squatter constructions and renewal of squatter areas;

- improving construction quality in urban settlements;

- regulating urban rent and increasing land supply;

- improving capacities for disaster mitigation;

- refurbishment and improvement of the existing housing stock;

- improving intra-urban transportation facilities;

- establishing adequate recreational areas;

- increasing the capacities of the local authorities;

- improving financing of urban infrastructure;

- improving financing of housing and improving delivery of housing;

- to form a model with sample applications;

- to enhance the optimum quality;

- to reduce the cost;

- to provide discipline and to prevent speculations through the sector;

- to provide housing construction in the regions in which the private sector services are insufficient;

- to apply renovation of squatter housing in cooperation with the municipalities;

- to provide contribution for the realization of a uniform distribution of the population within the whole territory of the country; and

- to enhance planned urbanization within the country.

\section{SWOT ANALYSIS FOR TURKEY AND LITHUANIA}

The SWOT analysis provides information about Strengths, Weaknesses, Opportunities and Threats in each country. The analysis of Strengths, Weaknesses, Opportunities and Threats has been carried out for both countries and is presented below.

\subsection{SWOT analysis for Turkey \\ Strengths:}

1. Economic, geographic and demographic scale of Turkey.

2. The conditions for EU membership are being fulfilled.

3 . Young and dynamic manpower.

4. International experience and knowledge.

5. Existence of construction tradition.

6. Quality and strength of construction materials manufactured.

\section{Weaknesses:}

1. Negative aspects of the national economy and limited investments.

2 . Negative aspects of the utilization of resources.

3. Insufficient capital accumulation and financial substructure.

4. Possibility of a failure to become an EU member.

5. Problems with enforcement of the laws and regulations.

6. Negative aspects of the bureaucratic structure of the state.

7. Insufficient education level.

8. Insufficient national R\&D substructure and funds.

9. Insufficient cooperation between universities and industrialists.

10. Unhealthy competition in the sector.

11. Some of the companies acting in the construction sector do not respect business ethics.

\section{Opportunities:}

1. If the development rate set forth in the report can be continued, many resources will emerge that will lead to various opportunities. 
2. Opportunities arising from the need to renew the existing stock of infrastructures and buildings.

3. Opportunities that will arise from increase of directly inflow of foreign capital.

4. Opportunities arising from the demand for construction contracts in foreign markets, and from the possibility to get involved in reconstruction of damages suffered in certain countries due to various reasons.

5. Opportunities that may arise from the tourism sector development.

6. Opportunities to benefit from educational institutions of EU member states as part of the process of EU accession.

\section{Threats:}

1. Earthquakes may lead to devastation.

2. The risk of war in the region.

3. Reasonable and steady governance might not be achieved (i.e. economic and social instabilities).

4. Economic crisis might continue (growth rate may not be increased).

5 . R\&D level necessary to catch up with the technological level of the industrialized countries might not be ensured.

6. Education level of technical manpower might not be raised; professional engineering might not be established as a profession.

Source: (The Scientific \& Technological Research Council of Turkey, 2004).

\subsection{SWOT Analysis for Lithuania}

\section{Strengths:}

1. Rather stable political and economic situation.

2. The main market agencies established and the economic development provision provided.

3. Integration into the EU.

4. Stable growth of investment rating of Lithuania.

5. Favourable loan terms and conditions.

6. Insurance of housing loans.

7. A strong housing construction basis.

\section{Weaknesses:}

1. Lithuanian economic development stands behind the EU members.

2. Low income of the population.

3. Limited housing choices.

4. A weak rental housing sector.

5. Inefficient residential energy consumption.

6. Issues related to land use and restitution of ownership rights.

7. Dispersed and rather weak institutional capacity to coordinate the implementation of housing policy.

8. Ineffective use of budget funds for housing subsidies.

9. Lack of a comprehensive information system for the housing sector.

10. An incomplete legal basis.

11. Insufficient ownership awareness of owners.

\section{Opportunities:}

1. A bigger national budget resulting from the growing economy and EU membership benefits.

2. Development of banks and other credit institutions, their increasing capital, bigger supply of new crediting products.

3 . The construction sector getting stronger.

4. The organizational and technical capacity of the housing market players underdeveloped.

5. More active participation of NGOs, nonprofit organizations and communities when solving the housing problems.

\section{Threats:}

1. Demographic changes due to migration and ageing.

2. Increasing social segregation.

Source: (Government of the Republic of Lithuania, 2004). 


\subsection{Results of the SWOT analysis: differences and similarities}

\section{DIFFERENCES:}

- Turkey suffers economic problems and limited investments, but there are a number of positive developments. Lithuania is steadier in political and economic terms.

- There is the risk of failure to integrate to the EU. Significant contributions can be enjoyed due to EU membership.

- Turkey does not grow steadily but Lithuania grows steadily.

- House insurance is an established system in Lithuania but it is still new for Turkey.

- Lithuania can obtain administrative and monetary support from the EU to solve its housing problems and allocates considerable funds to do so; but there are no funds in Turkey apart from the T.O.K.I. projects to solve the same problem.

- In Lithuania overall demand for houses is low due to aging population and immigrations so that investments are low too but there is the need for restoration. In Turkey population grows by approximately $1,5 \%$, so that it is much higher than the average growth rate of the European countries, and local migration from rural areas to cities causes the overall demand for housing to increase seriously.

\section{SIMILARITIES:}

- Low-income is an obstacle making it difficult for the people to buy houses.

- Number of the houses for rent is limited, thus the demand for them accumulates.

- No institutionalism in application of housing policies.

- Data about the housing sector cannot be collected at a sufficient level.

- Legal substructure has not been settled yet.

- A common aspect of the two countries is that their construction sectors are growing and gaining strength.

\section{CONCLUSIONS}

Analysis of the housing stock of Lithuania of the period from 1995 to 2003 showed that urban and rural housing stocks have not increased substantially during the period. Due to the decreasing population, migration and government policies, investments in housing have not increased; however, investment in non-residential real estate has increased.

Analysis of housing policies of both countries showed that they have many points in common. For example, priorities are set to supply houses to lower income groups, and initiatives are still continued to create new residential areas and to increase the quality.

Unscheduled urbanization and unsettledness of legal and institutional infrastructure have resulted in urban sprawl of big cities in Turkey. The unbalanced distribution of economic growth among geographic regions increased the migration from countryside to towns and created a housing style, away from any notion of architecture and engineering, which we call "shanty"; it resulted from attempts of individuals to satisfy their accommodation needs by themselves, and consequently the housing problem continued increasing. In the recent years, long-term financing opportunities have been brought forth through establishing economic stability, and attempts towards setting housing policies have been increased in parallel.

Lithuania has entered into a new rapid privatization process after having regained its independence in 1990, and studies attempting to harmonize housing policies with the requirements have been sped up in the wake of its EU membership.

Although the basic problems for both countries are financial, it was also observed that there were drawbacks in the legal and administrative infrastructure as well as in institutional structure of applications and problem coordination.

These developments can be listed as real estate sector institutionalisation, registered 
transactions, increasing standards, increase in competition and quality with the entrance of the foreign investors and other agents of real estate sector, increase in purchases and mergers. During full membership, foreign investment will increase just like it did in other countries.

\section{REFERENCES}

Belniak, S. (2004) The Polish real estate market in the context of the EU enlargement, Paper Presented at the $11^{\text {th }}$ European Real Estate Conference, 2-5 June 2004, Milan, Italy, pp. 1-9.

The Building Information Centre (2004) Turkish Construction Sector Report, Yapi Endüstri Merkezi, Istanbul. (In Turkish).

Cutts, A. C. and Olsen, E. O. (2002) Are Section 8 housing subsidies too high? Journal of Housing Economics, 11(3), p. 214-243.

Gallent, N. (2005) Regional Housing Figures in England: Policy, Politics and Ownership. Housing Studies, 20(6), p. 973-988.

Government of the Republic of Lithuania (2004) The Lithuanian Housing Strategy, Government of the Republic of Lithuania; < http://www.am.lt/ VI/en/VI/files/0.386991001107419000.doc > [accessed 200504 14].

GYODER (2005) Country Information May 2005, Turkey - "The Big Picture", The Association of Real Estate Investment Companies GYODER.

Housing Development Administration of Turkey (2005) <http://www.toki.gov.tr/english/ recent.asp > [accessed 20050510 ].

Housing Undersecretariat (2002) The Housing Demand Research of Turkey, 2000-2010, Housing Undersecretariat/APK (Research, Planning and Coordination) Office Department.

Houstoun, F. (2005) Housing America State by State: How Governors Are Leading the Way. Housing facts \& findings, 7(1); http:// www.fanniemaefoundation.org/programs/hff/ v7i1-housing.shtml> [accessed 200504 14].

Ivanicka, K. and Spirkova, D. (2004) Housing Finance in Slovakia on the threshold of joining EU, Paper Presented at the $11^{\text {th }}$ European Real Estate Conference, 2-5 June 2004, Milan, Italy, p. 1-18.

Jonaitis, V. and Naimavičiené, J. (2004) Social and Regional Aspects of Housing Situation in
Lithuania. International Journal of Strategic Property Management, 8(4), p. 231-239.

Jonaitis, V. and Naimavičiene, J. (2003) Analysis of Housing Sector in Lithuania. International Journal of Strategic Property Management, 7(4), p. 172-182.

Keivani, R., Mattingly, M. and Majedi, H. (2004) Enabling housing markets or increasing low income access to land, Paper Presented at the $11^{\text {th }}$ European Real Estate Conference, 2-5 June 2004, Milan, Italy, p. 1-31.

Kim, K. -H. (2004) Housing and the Korean economy. Journal of Housing Economics, 13(4), p. 321-341.

Lahr, M. L. and Gibbs, R. M. (2002) Mobility of Section 8 families in Alameda County. Journal of Housing Economics, 11(3), p. 187-213.

Lee, M. (2004) Sustainable housing - realistic goal, or fantasy? An evaluation of housing policies in Lithuania, University of Cambridge.

Nothaft, F. E. and Perry, V. G. (2002) Do mortgage rates vary by neighbourhood? Implications for loan pricing and redlining. Journal of Housing Economics, 11(3), p. 244-265.

OECD (2002) Country paper, Lithuania, Organisation for Economic Co-operation and Development; <http://www.oecd.org/dataoecd/32/31/ 1844441.pdf> [accessed 200504 02].

Ortalo-Magne, F. and Rady, S. (2002) Tenure choice and the riskness of non-housing consumption. Journal of Housing Economics, 11(3), p. 266-279

The Scientific \& Technological Research Council of Turkey (2004) http://vizyon2023.tubitak.gov.tr/ (in Turkish) [accessed 200504 02].

Seko, M. (2002) Nonlinear budget constraints and estimation: effects of subsidized home loans on floor space decisions in Japan. Journal of Housing Economics, 11(3), p. 280-299.

State Planning Organisation (2001) Long-Term Strategy and Eighth Five Year Development Plan 2001-2005, State Planning Organisation, Ankara, 2001; <http://ekutup.dpt.gov.tr/plan/ viii/plan8i.pdf> [accessed 200504 25].

Statistics Lithuania (2005) Statistical Yearbook of Lithuania, Department of Statistics to the Government of the Republic of Lithuania, Vilnius.

Tsenkova, S. (2004) Lithuanian Housing Strategy Monitoring and Implementation, Ministry of Environment of Republic of Lithuania. 
Turkish Statistical Institute (2004a) Gross National Product by Sectors for Year 2004, Turkish Statistical Institute; <http://www.die.gov.tr/english/ index.html $>$ [accessed 200504 12].

Turkish Statistical Institute (2004b) Developments in Domestic Labour Market in Turkey, Main indicators of economic and social development, Turkish Statistical Institute; <http:// www.die.gov.tr/english/index.html $>$ [accessed 200504 12].

UNCHS (2000) Report of the Regional Workshop on Housing and Environment, United Nations Centre for Human Settlements, UNCHS (Habitat), HS/596/00E.
UNECE (2000) Country Profiles on the Housing Sector - Lithuania, United Nations Economic Commision for Europe UNECE, ECE/HBP/117.

UNECE (2004) Bulletin of Housing Statistics for Europe and North America 2004, United Nations Economic Commision for Europe UNECE, <http://www.unece.org/hlm/prgm/hsstat/ Bulletin_04.htm > [accessed 200505 02].

Wong, G. (2004) Dynamics of the Housing Markets in Hong Kong and Singapore: A comparison of two Cities, Paper Presented at the $11^{\text {th }}$ European Real Estate Conference, 2-5 June 2004, Milan, Italy, p. 1-23.

\section{SANTRAUKA}

\section{BŪSTO POLITIKOS TURKIJOJE IR LIETUVOJE LYGINAMOJI ANALIZE்}

\section{Feyzullah YETGIN, Natalija LEPKOVA}

Būsto sektorius yra labai svarbus sektorius visame pasaulyje. Didelę ịtaką būsto sektoriui turi finansavimas, remontai, valdymas, vertinimas, mokesčiai, gyventojų skaičius. Straipsnyje atliekama būsto politikos Turkijoje ir Lietuvoje lyginamoji analizè, pateikiami Turkijos ir Lietuvos būsto strategijų bendri bruožai ir skirtumai, analizuojami strategijų principai ir prioritetai. Analizuojama gyventojų skaičiaus įtaka būsto sektoriui. Akcentuojami tam tikri ekonominiai aspektai. Ištirta ir pateikta socialinio būsto politika nagrinejjamose šalyse. Pateikiamos būsto problemos dviejose analizuojamose šalyse. Atskiras dẻmesys nukreiptas ị subalansuotą būstą ir socialinę sanglaudą būsto srityje, taip pat apžvelgta būsto nuomos rinka bei susijusios problemos. Pateikiama Turkijos ir Lietuvos SSGG analizè. 